\title{
速崩壊錠に対する軽度嚥下障害患者の評価
}

\author{
松里軒浩一*, 山口正彦, 中田 宏 \\ エーザイ株式会社 EMP 研究室†
}

\section{Clinical Evaluation of Rapidly Disintegrating Tablets in Patients with Mild Dysphagia}

\author{
Koichi Shoriken*, Masahiko Yamaguchi and Hiroshi Nakata \\ EMP (Elderly Medicine Project) R\&D Section, Eisai Co., Ltd.†
}

$\left[\begin{array}{l}\text { Received November 20, } 2002 \\ \text { Accepted June 29, } 2003\end{array}\right]$

\begin{abstract}
Rapidly disintegrating tablets ("EMP-tablet", developed by Eisai, Co., Ltd.) are developed based on a formulation that is expected to make the swallowing of medicines easier for patients with mild dysphagia. To evaluate the sensation of the oral administration of such "EMP-tablets", the authors conducted a study in patients with mild dysphagia. After the administration of both "EMP-tablets" and uncoated compressed tablets of consisting of the same components and the same appearance (plain tablet), the sensation of their oral administration and other benefits such as size and so on, were compared for both tablets.

The 25 subjects with mild dysphagia, who participated in the trial were asked to respond to the question "which tablet was easier to swallow?". The rate of positive responses for the "EMP-tablet" was 76\%, which was significantly better $(p=0.0013)$ than the response for the "plain tablet". Regarding the question about the size of a tablet, although only $28 \%$ responded "It is no problem" before oral administration, the response improved to $80 \%$ after oral administration. In addition, there was also a statistically significant difference $(\mathrm{p}=$ $0.0096)$ in the ratio of patients who required less water for the oral intake of "EMP-tablets" than "plain tablets" (60\% vs $16 \%)$.

Consequently, in patients with mild dysphagia, the clinical benefits of "EMP-tablets" were clearly observed regarding the level of satisfaction during oral administration (tablet size and so on, as well as the required amount of drinking water) in comparison to "plain tablets".
\end{abstract}

Keywords — clinical evaluation, mild dysphagia, swallow, rapidly disintegrating tablet, EMP-tablet, plain tablet

\section{緒言}

介護力強化病院などにおける高齢者409例を対象とし

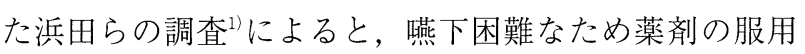
に際して，錠剤を粉砕するなど何らかの特別な工夫を 行っている割合は，11.5\%と報告されている．このよう に生理機能の低下した高齢者においては, 服用という行
為がかなりの負荷となるため, 臨床現場で特別な工夫を 行っている現状がある.

そこで近年, 高齢者向け薬剤というものを剂形面から 考えていく研究が，製薬企業で活発となった ${ }^{2-5)}$. その ひとつに速崩壞性の錠剤の開発が挙げられる，われわれ は多孔質の三次元構造を有する速崩壊錠 EMP 錠(Eisai Molded Premium-Tablet)を開発するに至った. EMP 錠は

† 文京区小石川 4-6-10；4-6-10, Koishikawa, Bunkyo-ku, Tokyo, 112-8088 Japan 
崩壊が速やかで，崩壊時の水への分散性が高いことか ら，脱カプセルまたは錠剤を粉砕して服用している高齢 者などに対しても, 特別な加工を必要とせずに服用可能 な優れた錠剤となる可能性がある.

そこで, EMP 錠の臨床上の便益性を検証するために, 軽度の蟮下困難を有する患者を対象として, EMP 錠と 一般的な圧縮錠 (素錠) との服用感についての比較試験を 実施したので報告する。

\section{試 験 方 法}

\section{1. 実施医療機関}

本試験は, 東京都老人医療センター (13例), 東京都立 大塚病院 $(10$ 例 $)$, 東京都多摩老人医療センター ( 2 例 $)$ に おいて実施した。実施に先立って，実施医療機関におい て審査され承認を得た。試験は，医師および薬剤師立ち 会いのもと実施し，試験中に有害事象が発生した場合に は適切な処置を行うこと，また，対象者から中止の申し 出があった場合などは，速やかに試験を中止することと した。なお，この試験実施に先立ち，医師より，対象者 本人に試験の説明を十分に行い，対象者からの同意を文 書にて取得した。

\section{2. 対象患者}

試験に先立ちアンケートを実施し，(1)軽度の嚥下困難 を判定するための質問「錠剤を飲むとき飲みにくいこと がありますか?」，(2)日常生活における誤嚥の典型的症 状と報告(6)されている質問「食事中にむせることがあり ますか? ，（3)「食後に咳达むことがありますか？」の いずれかひとつ以上に「はい」と回答した軽度嚥下障害 患者で正常な味覚を有し，自己回答能力のある25名を対 象とした。

対象者の性別は, 女性11名, 男性14名であり, 年齢(平 均土標準偏差) は, 55〜88歳 (71.7 7 7.95歳)であった。

\section{3. 試験製剂}

試験製剤は，EMP 錠および素錠とし，いずれも直径 約 $9.5 \mathrm{~mm}$, 厚さ約 $4.1 \mathrm{~mm}$, 白色で外観を似せた主薬を 含有しないプラセボ製剤を用いた。錠剤の大きさは， EMP 錠の技術を用いた市販している速崩壊錠 8 品目と 同等な直径および厚さとした，両製剤の処方には，表 1 に示した賦形剂のマンニトールを中心とした処方を用い た、EMP 錠の調製方法 ${ }^{5)}$ は，賦形剂を混合し，エタノー ルを加え練合した湿式粉体を成型後，乾燥した。素錠の 調製方法は，D-マンニトール，トウモロコシデンプン， 結晶セルロースおよびポリビニルピロリドン K30を混合 し，精製水を加え造粒，乾燥および整粒した粉体に，ス
テアリン酸カルシウムを混合後，打錠した。表 2 に試験 製剤の物性值を示した。

\section{4. 調查方法}

最初に 2 製剤 (EMP 錠および素錠)を対象者の前に並 べて，錠剤の大きさに関する質問を行った，その後，対 象者は EMP 錠および素錠を組み合わせ表に従い，第一 薬，第二薬の順に 1 回 1 錠ずつ水とともに服用した。た だし，開始にあたっては，少量の水で口腔内を湿らせて から行うこととし，できるだけ速やかに服用することに 留意した.薬剤の服用に際して飲水量は自由としたが, 1 回の服用に何 $\mathrm{mL}$ の水を必要としたかについて, 調査表 に記載した。

\section{5. 評価項目}

1）服用感の優劣の評価

$\mathrm{EMP}$ 錠と素錠間の服用感について，2 製郕服用後の 優劣を評価した。また，対象者がそれを判断した理由に ついて調査した。

2 ）服用前の錠剂の大きさに関する評価

錠剂を服用する前後に，錠剤の大きさに関する質問を 行った。

3 ）服用時の飲水量の評価

第一薬および第二薬を服用する際に使用した水の量を それぞれ調査した。

4) EMP 錠の評価

飲食物については，その舌触り，べたつき感および口 腔内残留感などのテクスチャーと飲み込みやすさとの相 関が報告7)されていることから，EMP 錠のテクスチャー を調査する目的で，舌への違和感に関する質問を行っ た。

\section{6. 統計解析方法}

2 製剤の服用感の優劣に対する選択率について，「変

表 1. 試験製剂の処方

\begin{tabular}{|c|c|c|c|c|}
\hline \multirow[t]{2}{*}{ 成分 } & \multicolumn{2}{|c|}{ 配合量 } & \multirow[t]{2}{*}{ グレード } & \multirow[t]{2}{*}{ 配合目的 } \\
\hline & EMP 錠 & 素錠 & & \\
\hline D-マンニトール & $275.8 \mathrm{mg}$ & $175.9 \mathrm{mg}$ & 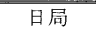 & 賦形斎 \\
\hline トウモロコシデンプン & $0.7 \mathrm{mg}$ & $91.6 \mathrm{mg}$ & 日局 & 賦形剂 \\
\hline 結晶セルロース & $0.7 \mathrm{mg}$ & $91.6 \mathrm{mg}$ & 日局 & 賦形剤 \\
\hline ポリビニルピロリドン K30 & $2.8 \mathrm{mg}$ & $7.2 \mathrm{mg}$ & 日局 & 結合剤 \\
\hline ステアリン酸カルシウム & 微量 & $3.7 \mathrm{mg}$ & 日局 & 滑沢剤 \\
\hline 総量 & $280.0 \mathrm{mg}$ & $370.0 \mathrm{mg}$ & & \\
\hline
\end{tabular}

表 2. 試験製剤の物性值

\begin{tabular}{|c||c|c|c|c|}
\hline & 直径 $(\mathrm{mm})$ & 厚さ $(\mathrm{mm})$ & 硬度 $(\mathrm{kg})$ & 崩壊 $^{\text {a) }}$ (秒) \\
\hline EMP 錠 & $9.5 \pm 0.09$ & $4.1 \pm 0.04$ & $5.9 \pm 1.12$ & $22.7 \pm 7.39$ \\
\hline 素錠 & $9.6 \pm 0.005$ & $4.1 \pm 0.01$ & $4.9 \pm 0.31$ & $149.0 \pm 28.17$ \\
\hline a) 日局崩壊試験法に基づいて目視により観測した.
\end{tabular}


わらない」と回答した対象者を除いて二項検定 ${ }^{8}$ を行っ た。また，服薬時どちらの製剤の飲水量が少なかったか を対象者ごとに調査し，同量であった対象者を除いて二 項検定委を行った．有意水準はいずれも両側 $5 \%$ とし た。

\section{結果および考察}

EMP 錠の臨床的便益性を検証するため, 軽度の苝下 能力低下が認められる患者を対象とし，現在市販してい る EMP 錠と製剤物性抢よび主な賦形剤をほぼ同一にし たプラセボ錠を用いて，速崩壊性を有しない一般的な圧 縮錠プラセボ錠と飲み比べることにより，その服用感な どの便益性を比較検討する試験を実施した。

表 3 に示した EMP 錠と素錠間の服用感評価について の質問「飲みやすかったのはどちらですか？」に対する 回答結果に扮いて，「EMP錠」と回答した例は19名 (76.0\%)であり，「素錠」の選択率(16.0\%)に比べて有 意 $\left(\mathrm{p}=0.0013^{* *}\right)$ に高い結果であった。質問の判定理由 を表 4 に示したが，EMP 錠は口腔内で溶けるからよい とする理由が57.9\%と最も多かった。また，素錠の方が 飲みやすかったと回答した 4 名は，素錠がスムーズに飲 み込めたことを理由にしており，その場合は速崩壊錠の 必要性が低いことが示唆される。

表 5 に示した EMP 錠の評価に関する質問の回答結果

表 3. 服用感調査結果

\begin{tabular}{|c|c|c|}
\hline 調査項目 & 回答 & 対象者数 \\
\hline \multirow{3}{*}{$\begin{array}{l}\text { 飲みやすかったのはどちら } \\
\text { ですか? }\end{array}$} & EMP 錠 & 19 名 $(76.0 \%)$ \\
\hline & 素 錠 & 4 名 (16.0\%) \\
\hline & 変わらない & 2 名 $(8.0 \%)$ \\
\hline \multicolumn{2}{|l|}{ 検定 ${ }^{\text {a) }}$} & $0.0013^{* *}$ \\
\hline
\end{tabular}

表4.「飲みやすかったのはどちらですか?」の質 問の判定理由(複数回答可)

\begin{tabular}{|c|c|}
\hline 項目 ${ }^{\text {a) }}$ & 対象者数 \\
\hline \multicolumn{2}{|l|}{ 1.「EMP 錠がよい」と回答した理由 } \\
\hline 1）口腔内で溶けるからよい & 11 名 $(57.9 \%)$ \\
\hline 2）飲み込むとき異物感（不快感）がないからよい & 6 名 $(31.6 \%)$ \\
\hline 3）味があるからよい & 4 名 $(21.1 \%)$ \\
\hline 4）その他 & 6 名 $(31.6 \%)$ \\
\hline (1)スッとしたような感じで口の中に入りやすい & 1 名 \\
\hline (2)このくらいの大きさなら無理なく服用できる & 1名 \\
\hline (3)EMP 錠はなめらか, 小さく感じた & 1 名 \\
\hline $\begin{array}{l}\text { (4)すぐに飲み込めた, 素錠は口の中で浮いている感じ } \\
\text { で飲みにくかった }\end{array}$ & 1 名 \\
\hline (5)自然に飲み込めた & 1名 \\
\hline (6)特にない, あえていえばこちら & 1名 \\
\hline 総回答者数 & 19 名 \\
\hline \multicolumn{2}{|l|}{ 2.「素錠がよい」と回答した理由 } \\
\hline 1）EMP 錠は舌でざらつく & 1 名 $(25.0 \%)$ \\
\hline 2）その他 & 4 名 $(100 \%)$ \\
\hline すぐに飲み込めるのでよい，つるつと入ったから & 4 名 \\
\hline 総回答者数 & 4名 \\
\hline
\end{tabular}

a）項目には，集計後に見やすさの点から番号を付けた。
において，錠剤の大きさに関する質問では，服用前は「大 きすぎる」と回答した例が17名(68.0\%)，「ちょうどよ い」と回答した例が 7 名 $(28.0 \%)$ であったのに対して， 服用後は「大きすぎる」と回答した例は 5 名 $(20.0 \%) に$ 減少し，「ちょうどよい」と回答した例は 20 名 $(80.0 \%)$ に増加した。使用した錠剂は，取り扱いやすさを考慮し 直径約 $9.5 \mathrm{~mm}$ ，厚さ約 $4.1 \mathrm{~mm}$ であり，他剂を含めた市 販錠剤のなかでは，大きい方に分類されると考えられ る。一般的に大きい錠剂の方が摘みやすいが，服用時に 與下しにくいという問題が同時に発生する。しかし，今 回の結果が示すように，錠剤の大きさについての質問 で，服用前は「大きい」との印象が認められたものの， 服用後は「ちょうどよい」と回答した例が $80.0 \%$ であっ たことから，EMP 錠は嚥下という点に関しては問題が ないと考えられた。錠剤の大きさと服用のしやすさの限 界について，山田らの報告9)では，健康人で直径 $9 \sim 9.5$ $\mathrm{mm}$ まで, 後藤らの報告 ${ }^{10)}$ では, 健康人で $8.5 \mathrm{~mm}$ まで, 入院患者で $9 \mathrm{~mm}$ まで，土谷らの報告 ${ }^{11)}$ では，外来維持 透析患者で $9 \mathrm{~mm}$ 以下と考察されている。これらの報告 より大きい錠剂でも，速崩壊性の錠剂であれば服用に問 題が発生しないことが示唆される.

EMP 錠は速やかに崩壊するように, 吸水能が小さく, 少量の水でも溶解速度が速い種類の糖類を添加 ${ }^{12)} し た$ 湿 式製造により，空隙率が大きく，水分が浸透しやすい構 造で設計されている。今回の試験において，対象者が EMP 錠と素錠を服用した時に，どちらの飲水量のほう が少なかったかについて，表 6 に示した．EMP 錠の飲 水量のほうが少なかった対象者は15名(60.0\%)，素錠の ほうが少なかった対象者は 4 名 (16.0\%)であり，有意差 $\left(\mathrm{p}=0.0096^{* *}\right)$ が認められた，丹野らの報告 ${ }^{13)}$ では，40 歳以上の外来患者 38502 名の平均併用薬剤数は 4.09 剂で あり，加齢に伴い薬剂数の上昇が認められる。これら多 剂併用時の飲水量を考えた場合，少ない水で服用可能な 製剤は負担を軽減すると思われる。一方，素錠の飲水量 のほうが少なかった 4 名について，1名は EMP 錠が口

表 5. EMP 錠の評価に関する質問

\begin{tabular}{|c|c|c|}
\hline 調査項目 & 回答 & 対象者数 \\
\hline \multirow{3}{*}{$\begin{array}{l}\text { 錠剤の大きさはどうですか? } \\
\text { (服用前) }\end{array}$} & 大きすぎる & 17 名 $(68.0 \%)$ \\
\hline & ちょうどよい & 7名 $(28.0 \%)$ \\
\hline & 小さすぎる & 1 名 ( $4.0 \%)$ \\
\hline \multirow{3}{*}{$\begin{array}{l}\text { 錠剂の大きさはどうですか? } \\
\text { (服用後) }\end{array}$} & 大きすぎる & 5 名 $(20.0 \%)$ \\
\hline & ちょうどよい & 20 名 $(80.0 \%)$ \\
\hline & 小さすぎる & 0名 \\
\hline \multirow[t]{2}{*}{ 舌に何か感じますか？ } & 特に感じない & 22 名 $(88.0 \%)$ \\
\hline & 感じる a) & 3 名 $(12.0 \%)$ \\
\hline
\end{tabular}


表 6. 試験製剂服用時の必要飲水量の比較

\begin{tabular}{|c|c|}
\hline 項目 & 対象者数 \\
\hline EMP 錠の飲水量のほうが少なかった & 15 名 $(60.0 \%)$ \\
\hline 素錠の飲水量のほうが少なかった & 4 名 $(16.0 \%)$ \\
\hline EMP 錠，素錠いずれも飲水量は同じだった & 6 名 $(24.0 \%)$ \\
\hline 検定 ${ }^{\text {a) }}$ & $0.0096^{* *}$ \\
\hline
\end{tabular}

腔内に残ったため再度水を飲んだことを理由として挙げ ており, 口腔内で崩壊させると賦形剤等の味が若干残存 し再度水を服用する場合もあると思われる。

EMP 錠のテクスチャー評価に関する質問に扔いて， 舌への違和感の質問では，「特に感じない」と回答した 例が22名 $(88.0 \%)$ であった。今回の評価で参考とした高 橋らの研究7では, 飲食物の舌触り, 心゙たつき感抢よび 口腔内残留感などのテクスチャーと飲み込みやすさとの 相関が報告されており，EMP 錠が舌への違和感が少な いことは，飲み込みやすさへプラスの要因となるものと 示唆された。

以上から, EMP 錠は同形状の素錠と比較して服用感 および飲水量軽減の点で優れ，大きさなどの取り扱いの 点でも支障なく, 軽度の嚥下障害患者に対して, 有用な 製片であると考えられた。

謝辞 本試験の実施当時, 東京都立大塚病院薬剂科 竹内 淳美先生, 東京都老人医療センター薬剤科 系井欣三先生, 東京都多摩老人医療センター薬剤科 岡野紘基先生(順不同) を始め各医療機関の医師および薬剤師の方々に多大なる御協 力を賜りましたことを深謝いたします。

\section{引用文 献}

1）浜田知久馬, 高橋泰, 中島研, 高齢者の服用介助 における負担度の定量解析の試み, 病院薬学, 21, 282-294(1995).

2）正木勝広，飲み込みやすい製剤，薬局， 51，14031407 (2000).

3）奥村睦男，茂木幸応，宮崎勝昭，ノンカロリー型 賦形剂の口腔内速溶錠への応用, PHARM TECH JAPAN , 14, 367-373(1998).

4) H. Seager, Drug-delivery Products and the Zydis Fast-dissolving Dosage Form, J. Pharm. Pharmacol ., 50, 375-382 (1998).

5) 対馬勇禧, 新規速崩錠および湿潤粉体打錠機の開 発，製剂機械技術研究会誌，10，5-17(2001).

6）藤島一郎, “脳卒中の摂食・嚥下障害”, 第二版, 医歯薬出版, 東京, 1998, pp. 55-57.

7）高橋智子, 大越ひろ，粘ちょうな液状食品の飲み 込み特性と力学的特性の関係, 日本家政学会誌, 50, 333-339 (1999).

8）市原清志, “バイオサイエンスの統計学”,第一版, 南江堂, 東京, 1990, pp. 18-21.

9）山田正幸, 沢村正寿, 松浦貞夫, 錠剤及びカプセ ル剂の服用のしやすさに及ぼす大きさと形状の影 響, 武田研究所報, 43, 111-115(1984).

10）後藤一，緒方宏泰，製剂の大きさと服用しゃすさ について，薬剤学，50，230-238(1990).

11）土谷隆紀, 縣宗彦, 藤井惠美子, 木全直樹, 二瓶 宏, 松井洋子, 大橋信子, 透析患者における内服 製剤の服用感に関する調査，医薬ジャーナル， 36, 1691-1697(2000).

12）大脇孝行, 高齢者向けの製剂, 粉体と工学, 33, 4248(2001).

13）丹野慶紀, 海野勝男, 高齢外来患者の薬物療法の 実態，医薬品相互作用研究，13，3-10(1989). 